\title{
WATER BALANCE IN SOIL CULTIVATED WITH FORAGE CACTUS CLONES UNDER IRRIGATION ${ }^{1}$
}

\author{
POLIANA DE CALDAS PEREIRA ${ }^{2}$, THIERES GEORGE FREIRE DA SILVA ${ }^{3 *}$, SÉRGIO ZOLNIER ${ }^{2}$, SÉRVULO $^{3}$ \\ MERCIER SIQUEIRA E SILVA ${ }^{4}$, MARCELO JOSÉ DA SILVA ${ }^{3}$
}

\begin{abstract}
Forage cactus species may belong to different genera (such as Opuntia and Nopalea), which can result in different water dynamics at the biosphere-atmosphere interface. The objective of this study was to analyze the water balance in soil cultivated with forage cactus clones under different conditions of soil water availability in the Brazilian semi-arid. The experiment was conducted in the municipality of Serra Talhada, State of Pernambuco. The crop was subjected to nine treatments arranged in a randomized complete block design with three replications in a factorial arrangement of $3 \times 3$. The plots were composed of three water availability conditions, with the application of a water depth of $7.5 \mathrm{~mm}$ at intervals of 7, 14, and 28 days, and the subplots consisted of three forage cactus clones (IPA Sertânia, Miúda, and Orelha de Elefante Mexicana). The soil water balance (SWB) method was applied, and the ET/ETo ratio was estimated (ET is the actual crop evapotranspiration, and ETo is the reference evapotranspiration) at intervals of 14 days; the results were represented in nine periods of 28 days. There was a difference between SWB components along the cycle and between irrigation conditions $(\mathrm{p}<0.05)$. Nevertheless, ET and rainfall were the most important components in SWB when irrigation was performed. There was no difference in water consumption between forage cactus clones belonging to different genera, resulting in an average of $1.50 \mathrm{~mm} \mathrm{day}^{-1}$. The ET/ETo ratio had low magnitude $(0.29 \pm 0.12)$, indicating that the ET was more dependent on the water regime than on the atmospheric demand.
\end{abstract}

Keywords: Evapotranspiration. CAM plants. Opuntia spp.. Nopalea sp..

\section{BALANÇO DE ÁGUA NO SOLO CULTIVAdO COM CLONES DE PALMA FORRAGEIRA SOB IRRIGAÇÃO}

RESUMO - A palma é uma espécie pertencente aos gêneros Nopalea e Opuntia, o que pode resultar em dinâmicas de água diferentes na interface biosfera-atmosfera. Assim, objetivou-se analisar o balanço de água no solo cultivado com clones de palma forrageira em diferentes condições de disponibilidade hídrica no Semiárido brasileiro. O experimento foi conduzido em Serra Talhada, PE. A cultura foi submetida a nove tratamentos, dispostos em delineamento em blocos ao acaso, com três repetições, em arranjo fatorial 3x3. As parcelas foram constituídas por três condições de disponibilidade hídrica com a aplicação de uma lâmina de 7,5 mm em intervalos 7; 14 e 28 dias, e as subparcelas por três clones de palma (IPA Sertânia, Miúda e Orelha de Elefante Mexicana). O método do balanço de água no solo (BAS) foi aplicado e a razão ET/ETo estimada (sendo, ET a evapotranspiração real da cultura e ETo a evapotranspiração de referência), em intervalos de 14 dias, e os resultados foram representados em nove períodos de 28 dias. Houve diferença dos componentes do BAS ao longo do ciclo e entre as condições de irrigação $(\mathrm{p}<0,05)$. Embora sob irrigação, a ET e a precipitação foram os componentes mais importantes no BAS. Não houve diferença no consumo de água entre os clones, ainda que pertencentes a diferentes gêneros, resultando média de 1,50 $\mathrm{mm} \mathrm{dia}^{-1}$. A razão ET/ETo possuiu baixa magnitude $(0,29 \pm 0,12)$, indicando que a ET foi mais dependente do regime hídrico do que da demanda atmosférica.

Palavras-chave: Evapotranspiração. Plantas MAC. Opuntia spp. Nopalea sp..

\footnotetext{
*Corresponding author

${ }^{1}$ Received for publication in $05 / 19 / 2016$; accepted in 12/12/2016.

Paper extracted from the master's dissertation of the first author, funded by FACEPE/CNPq/IPA/UFRPE.

${ }^{2}$ Department of Agricultural Engineering, Universidade Federal de Viçosa, Viçosa, MG, Brazil; po.caldas@hotmail.com, zolnier@ufv.br.

${ }^{3}$ Academic Unit of Serra Talhada, Universidade Federal Rural de Pernambuco, Serra Talhada, PE, Brazil; thieres_freire@yahoo.com.br, marcelosilva145@hotmail.com.

${ }^{4}$ Instituto Agronômico de Pernambuco, Arcoverde, PE, Brazil; servulo.mercier@yahoo.com.br.
} 


\section{INTRODUCTION}

Forage cactus (Opuntia spp. and Nopalea spp.) is the most important cactaceous plant for animal feeding in arid and semi-arid regions of the world (SILVA et al., 2014). It adapts to this environmental condition due to the morphophysiological mechanism CAM (crassulacean acid metabolism), which allows high water-use efficiency (HERNÁNDEZ et al., 2004; OLIVEIRA JUNIOR et al., 2009). Despite this characteristic, the development of this crop varies with the oscillations of meteorological conditions (OLIVEIRA et al., 2011), and irrigation is an alternative to meet its water requirements (QUEIROZ et al., 2015).

Information that characterizes plant responses to different levels of water availability is important for the definition of management strategies to improve the use of water by crops (CHILUNDO et al., 2016; KRESOVIĆ et al., 2016; TARI, 2016). One of the ways of acquiring this information is by means of the soil water balance (SWB) method. This method combines the inputs and outputs of water in a control volume, which extends from the vegetated surface to the effective depth and depends on the dimensions of the root system at a given time interval (LIBARDI, 2005). It allows the calculation of water consumption by the crop, that is, its evapotranspiration (ET) (WARD et al., 2012; HOWELL et al., 2015; KIREMIT, ARSLAN, 2016).

Under optimal conditions of cultivation, ET is called ETc (crop evapotranspiration), and its ratio with the reference evapotranspiration (ETo) represents the crop coefficient $(\mathrm{Kc})$, which varies according to the cropping system, the morphophysiological aspects of plants, and the local atmospheric demand (ALLEN et al., 1998). Under conditions of water limitation or inadequate management, ET is called ET (actual crop evapotranspiration), and the ET/ETo ratio indicates how much of the ET variation is due to soil water availability or to ETo (SILVA et al., 2015).

The water dynamics at the biosphere-atmosphere interface of forage cactusgrowing areas may be different, because their main clones belong to the two genera, Nopalea and Opuntia. In this way, the understanding of the variation of SWB components in forage forage cactus cultivation areas is essential for adequate water management in the production system (GHIBERTO et al., 2011). Nevertheless, research on forage cactus ET (HAN, FELKER, 1997; CONSOLI; INGLESE; INGLESE, 2013; SILVA et al., 2015) is scarce, especially under irrigated conditions in the Brazilian semi-arid. In view of the context, the objective of this study was to analyze the water balance in soil cultivated with forage cactus clones under different water availability conditions.

\section{MATERIAL AND METHODS}

The experiment was conducted at the experimental station of the Agronomic Institute of Pernambuco (IPA) (latitude: $7^{\circ} \quad 57^{\prime} \mathrm{S}$; longitude: $38^{\circ} 11^{\prime} \mathrm{W}$; altitude: $506 \mathrm{~m}$ ) in the municipality of Serra Talhada, a semi-arid region of northeastern Brazil. According to the Köppen Climate Classification, the predominant climate is type BSh'. The experimental area was approximately $864 \mathrm{~m}^{2}$ $(15 \times 57.6 \mathrm{~m})$, and its soil is classified as eutrophic Red-Yellow Argisol with a sandy loam texture.

Planting was carried out in February 2010, with three forage cactus clones, one of the genus Opuntia, called Orelha de Elefante Mexicana/IPA-200016, and the others of the genus Nopalea, called Miúda/IPA-100004 and IPA-Sertânia/IPA-200205. All clones were grown at a spacing of $1.6 \mathrm{~m}$ between rows and $0.2 \mathrm{~m}$ between cladodes, in a level curve, with $50 \%$ of their length buried in the soil. Cultivation was conducted under rainfed conditions during the first two years, which characterized the first biennial crop cycle. In March 2012, the first harvest was performed, in which only the basal cladode (cladode inserted in the soil that will originate other cladodes) remained in the field, beginning the second productive cycle of the crop, which comprises the experimental period of this study.

Over time, hand weeding was performed to eliminate invasive plants, and chemical products were applied for pest control (caterpillars with $0.15 \%$ Lorsban application and cochineal scale with $2 \%$ mineral oil). The fertilization followed the recommendations of the IPA, releasing $50 \mathrm{~kg} \mathrm{ha}^{-1}$ of NPK (14-0-18) in the cultivation line monthly.

The experiment was arranged in a randomized block design in a factorial scheme (3x3) with subdivided plots and three replications. The plots consisted of three water availability conditions (i.e., application of a fixed depth of $7.5 \mathrm{~mm}$ with irrigation every 7,14 , and 28 days), and the subplots consisted of three forage cactos clones (OEM: Orelha de Elefante Mexicana; MIU: Miúda; and IPA: IPA Sertânia). The experiment consisted of 27 subplots of $32 \mathrm{~m}^{2}(5 \times 6.4 \mathrm{~m})$ and $12.8 \mathrm{~m}^{2}(4 \times 3.2 \mathrm{~m})$ of useful area. The $7.5 \mathrm{~mm}$ depth was defined based on information collected from forage forage cactusproducing areas in the State of Rio Grande do Norte, where producers applied the $5.0 \mathrm{~mm}$ depth every 14 days. These reference values were used to establish the $7.5 \mathrm{~mm}$ depth at the three irrigation frequencies and the three clones.

A drip irrigation system was used, with self-compensating drippers spaced $0.4 \mathrm{~m}$, a nominal flow rate of $1.5 \mathrm{~L} \mathrm{~h}^{-1}$, and a system uniformity coefficient of $92 \%$ in all subplots. Irrigations began in June 2012. The first depths were standardized to reach field capacity $\left(0.31 \mathrm{~m}^{3} \mathrm{~m}^{-3}\right)$ and stabilize the canopy of the crop. Differences between treatments 
started only as of August 2012.

In order to monitor soil water content, an access tube was installed in each subplot, placed $0.10 \mathrm{~m}$ away from plants, in addition to a capacitive probe (Diviner@2000, Sentek Pty Ltd. Australia), which recorded relative frequency readings every $0.10 \mathrm{~m}$. Soil water content data were obtained at depths of 0.10 to $0.70 \mathrm{~m}$ at three-day intervals from June 2012 (when irrigation began) to February 2013 (end of experiment), comprising 252 days. The capacitive probe was calibrated according to Araújo Primo et al. (2015).

The ETo (mm day ${ }^{-1}$ ) was estimated using the standard Penman-Monteith method, parameterized in the bulletin 56 of the Food and Agriculture Organization of the United Nations - FAO (ALLEN et al., 1998) using the meteorological variables collected from an automatic station belonging to the National Institute of Meteorology (INMET), located about $1700 \mathrm{~m}$ away from the cultivation area. SWB was performed based on the inputs and outputs of soil water, considering a control volume limited to the depth of $0.60 \mathrm{~m}$, since the highest concentrations of forage cactus roots occur in the lowest layers (SILVA et al., 2014). Water inputs and outputs by subsurface flow $(\triangle \mathrm{SSF})$ were neglected due to the low slope of the area.

Thus, the SWB equation was written as:

$$
\mathrm{WS}=\mathrm{P}+\mathrm{I} \pm \mathrm{R} \pm \mathrm{Q}-\mathrm{ET}
$$

in which WS is the soil water storage variation $(\mathrm{mm}), \mathrm{P}$ is the pluviometric precipitation $(\mathrm{mm}), \mathrm{I}$ is the irrigation $(\mathrm{mm}), \mathrm{R}$ is the runoff $(\mathrm{mm}), \mathrm{Q}$ is the vertical flow of soil water $(\mathrm{mm})$, and ET represents the actual evapotranspiration $(\mathrm{mm})$.

WS was obtained by the difference of the values of water depth determined at each $0.10 \mathrm{~m}$ and integrated up to $0.60 \mathrm{~m}$ from the data measured by the capacitive probe. $\mathrm{P}$ was monitored by the automatic weather station, and I was defined according to the $7.5 \mathrm{~mm}$ depth. $\mathrm{R}$ was estimated by the Curve Number method, as described by Silva et al. (2015). Q, represented by deep drainage (DD, $\mathrm{mm}$; negative) and/or capillary rise $(\mathrm{CR}, \mathrm{mm}$; positive), was determined by the Darcy-Buckingham equation (LIBARDI, 2005):

$$
\mathrm{Q}=-\mathrm{K}(\theta) \frac{\Delta \psi \mathrm{t}}{\Delta \mathrm{z}}
$$

where $K(\theta)$ is the hydraulic conductivity of the soil, and $\Delta \psi \mathrm{t} / \Delta \mathrm{z}$ is the soil water potential gradient, between the 0.50 and $0.70 \mathrm{~m}$ layers, located below the lower limit and above the upper limit of the control volume $(0.60 \mathrm{~m})$, respectively. The parameter $\mathrm{K}(\theta)$, expressed in $\mathrm{m} \mathrm{h}^{-1}$, was estimated as a function of the soil water content, calibrated to the depth of $0.60 \mathrm{~m}$, using the instant profile method, as described by Silva et al. (2015). The total soil water potential gradient $(\Delta \psi \mathrm{t} / \Delta \mathrm{z})$, between the 0.50 and $0.70 \mathrm{~m}$ layers, was obtained by estimating the total soil water potential $(\psi t)$ for both depths in all 27 subplots by means of the soil water content values and the equation adjusted by Silva et al. (2015).

ET was quantified from the residue of the SWB equation (Equation 1), whose components were calculated for 14-day intervals and later represented in nine sub-periods of 28 days. The periods were (1) Jun 21, 2012 to Jul 18, 2012; (2) Jul 19, 2012 to Aug 15, 2012; (3) Aug 16, 2012 to Sep 12, 2012; (4) Sep 13, 2012 to Oct 10, 2012; (5) Oct 11, 2012 to Nov 07, 2012; (6) Nov 08, 2012 to Dec 05, 2012; (7) Dec 06, 2012 to Jan 02, 2013; (8) Jan 03, 2013 to Jan 30, 2013; and (9) Jan 31, 2013 to Feb 27, 2013.

For the nine periods, the ET/ETo ratio was calculated based on the cumulative ET of the different forage cactus clones under different water availability conditions and on the ETo. All values of the SWB components were compared by analysis of variance (ANOVA), and, when significant, the Tukey mean test was applied at the 5\% level of significance. In the comparison of these components along the cycle, ANOVA with time-repeated measures was considered.

\section{RESULTS AND DISCUSSION}

Between June 2012 and February 2013 (252 days), when the irrigation events occurred within the crop cycle, the ETo was, on average, $5.1 \mathrm{~mm} \mathrm{day}^{-1}$, equivalent to $1872 \mathrm{~mm}$ year $^{-1}$. The pluviometric precipitation totaled $170 \mathrm{~mm}$, which represented only $35 \%$ of the climatological normal of the mentioned period.

Regardless of the clone, the cactus received irrigation depths equal to 188,105 , and $68 \mathrm{~mm}$, according to the irrigation conditions, with frequencies of 7,14 , and 28 days, respectively. These values, added to the precipitation and the standardized depth $(159 \mathrm{~mm}$, received before August 2012, when the differentiation of depths according to treatments occurred), totaled $506 \mathrm{~mm}, 423 \mathrm{~mm}$, and $386 \mathrm{~mm}$, in that order. These values (equivalent to 675,564 , and $514 \mathrm{~mm} \mathrm{year}^{-1}$ ) are below the range quoted by Queiroz et al. (2015) in a survey conducted in the municipality of Serra Talhada, where the depths of 1048 to $1096 \mathrm{~mm} \mathrm{year}^{-1}$ provided the best productive performances for the forage cactus Orelha de Elefante Mexicana clone. Hernández et al. (2004) report the application of irrigation depths from $740 \mathrm{~mm}$ year $^{-1}$ to $1380 \mathrm{~mm}$ year $^{-1}$ without significant increases in the production of cactus clones.

Although forage cactus plants present the 
morphophysiological mechanism CAM, when studying them, Scalisi et al. (2016) report, under water deficit, a reduction in the thickness, relative water content, malic acid accumulation, stomatal conductance, size, and rate of cladode development. Notwithstanding, this species maintains the same growth and stomatal conductance with relative water content above $45 \%$ in the cladodes, which is extremely low when compared to non-cactaceous species. In addition, forage cactus has high cladode rehydration capacity after long periods of drought, which suggests that regulated reductions in irrigation may not significantly affect plant biomass.

In the nine periods of the cycle, the vertical flow of soil water (Q) occurred only in the form of deep drainage (Figure 1). Moreover, there was no effect of the clone factor on $\mathrm{Q}(\mathrm{p}>0.05 ; \mathrm{F}=2.15)$, whereas it varied according to the cycle period (Figure 1A) $(\mathrm{p}<0.05 ; \mathrm{F}=13.6)$, the irrigation condition (1B) $(\mathrm{p}<0.05 ; \mathrm{F}=6.7)$, and the interaction of these factors (Figure $1 \mathrm{C})(\mathrm{p}<0.05$; $\mathrm{F}=3.0$ ).

Period 2 had the highest $\mathrm{Q}$ in response to the applications of uniform irrigation depths, low atmospheric demand, and reduced forage cactus growth soon in the first months of the cycle (Figure 1A). In this situation, the water absorption is reduced due to lower crop water demand (ARAÚJO PRIMO et al., 2015). On the other hand, in period 8 , when the highest pluviometric precipitation $(96.2 \mathrm{~mm})$ occurred, deep drainage was low due to successive antecedent days (periods 3 to 7) with low water input (totaling less than $50 \mathrm{~mm}$ per period) and because of the increased water consumption by plants. Similar results are cited by Silva et al. (2015), who studied the same cactus clones under rainfed conditions between 2010 and 2012 in Serra Talhada, PE.

The irrigation condition with a 14-day frequency obtained higher magnitudes of Q, although it did not differentiate from the 7-day condition, the latter not differing from the 28-day condition (Figure 1B). Under low water availability (i.e., 28 days), Q tends to be reduced, while under greater water input in the control volume, the ET process is intensified. In the cactus production system, this process is even faster, even after low water replenishment events, since the crop has a high capacity to form roots in the most superficial layers of the soil, called "rain roots," which die as soon as the soil water content decreases (DUBROVSKY; NORTH; NOBEL, 1998). The highest values of $\mathrm{Q}$ occurred in the irrigation condition of 14 days in periods 2, 3, and 9 (Figure $1 \mathrm{C})$, precisely at moments of greater soil water input or thereafter.

WS was also influenced by the cycle period $(\mathrm{p}<0.05 ; \mathrm{F}=149.8)$ (Figure $2 \mathrm{~A})$, the irrigation condition $(p<0.05 ; \mathrm{F}=8.5)$ (Figure $2 \mathrm{~B}$ ), and the interaction between these factors $(p<0.05 ; F=3.9)$
(Figure 2C). Period 2, followed by the 1st and 8th periods, had the highest WS; the 6th and 7th periods were also positive. More negative values occurred in periods 3 and 9 , subsequently to the moments of greater water availability $(1,2$, and 8 , in that order). We observed the smallest variations of WS in the irrigation condition of 28 days (Figure 2B). This frequency in periods 3 and 9 presented the lowest magnitudes of the experimental cycle (Figure 2C).

The WS magnitude, although subsequent to soil water input events or a long drought period, depends on the intensity of irrigation or pluviometric precipitation, the initial volumetric moisture, the hydro-physical characteristics of the soil, the atmospheric demand, and the water absorption capacity and distribution by the root system (DUBROVSKY; NORTH; NOBEL, 1998; GHIBERTO et al., 2011). Similarly to Q, WS was not different among forage cactus clones. Silva et al. (2015) also did not verify modification of WS in areas cultivated with these three clones under rainfed conditions. This result may be indicative of the similarity of the growth dynamics of the root system of these clones. Notwithstanding, Snyman (2006) points out that the adaptation of forage cactus species to different environments with water stress depends on the number of areoles existing in the most varied formats and sizes of cladodes in contact with the soil and on the capacity to alter root development due to variations in soil water availability.

Similarly to Q and WS, the ET of the forage cactus crop did not show a clone factor effect $(\mathrm{p}>$ $0.05 ; \mathrm{F}=2.0)$, whereas it varied according to the period $(\mathrm{p}<0.05, \mathrm{~F}=102.4)$ (Figure $3 \mathrm{~A})$, the irrigation condition $(\mathrm{p}<0.05 ; \mathrm{F}=18.0)$ (Figure 3B), and the interaction of these factors $(\mathrm{p}<0.05 ; \mathrm{F}=$ 5.3) (Figure 3C). The highest ET values occurred in period 8 , when the greatest rainfall event happened $(96.2 \mathrm{~mm})$, followed by periods 3 and 9 , which are successive to the time of application of the standardized depth and lowest atmospheric demand (3), and to the higher water availability in conjunction with the period of highest ETo (9). ET was more intensified under the condition of irrigation every 7 days when compared to the other water regimes (Figure 3B), especially in periods 3, 8, and 9 (Figure 3C).

In the present study, there was no difference in ET between the clones, but Silva et al. (2015), studying them under rainfed conditions, verified that Miúda responds faster to the soil water input than IPA Sertânia and Orelha de Elefante Mexicana. However, under conditions of water restriction, the latter two are able to maintain water consumption for a longer period when compared to Miúda, which supposedly gives the IPA Sertânia and Orelha de Elefante Mexicana greater adaptability to semi-arid environments. 
(a)
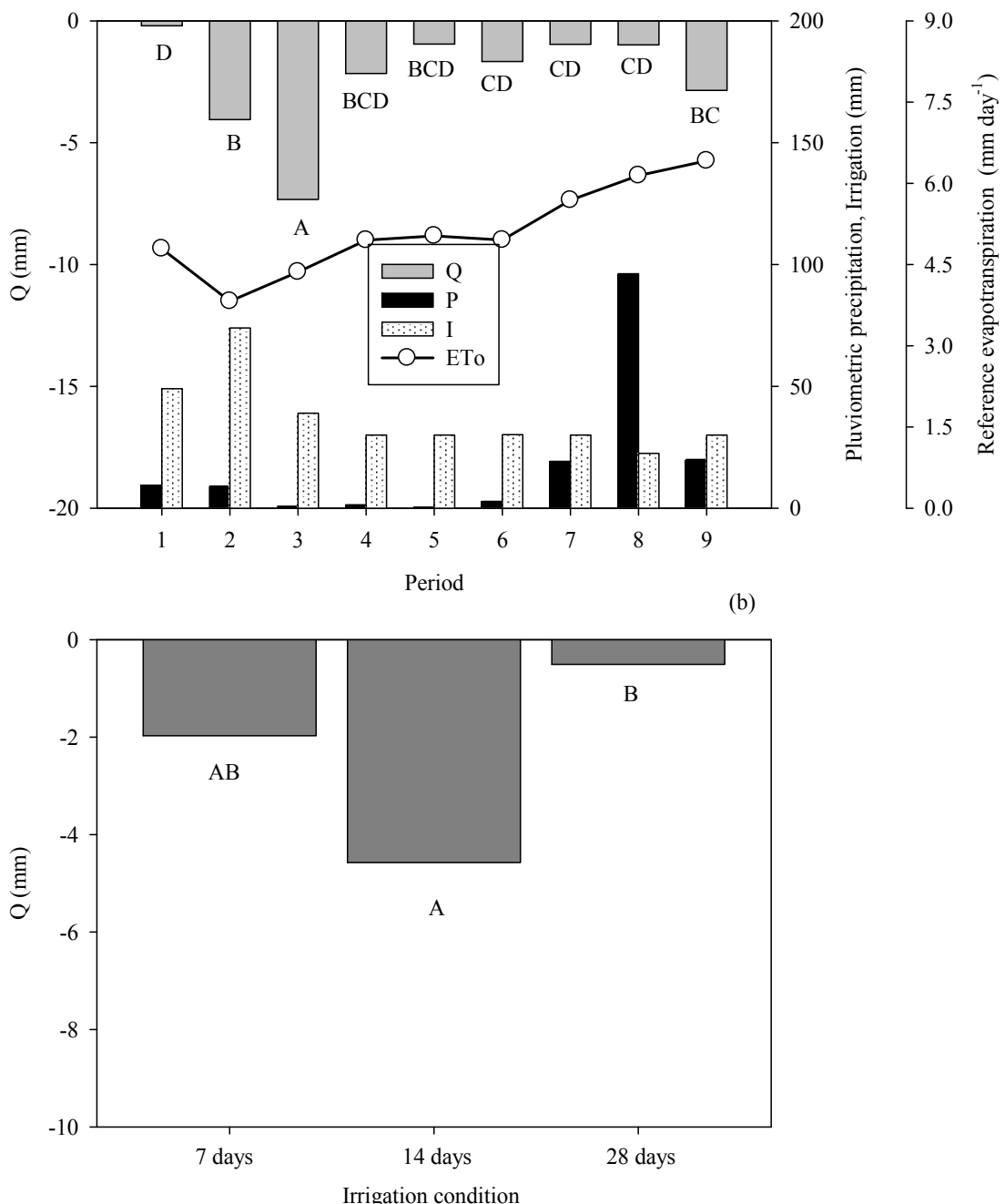

(c)

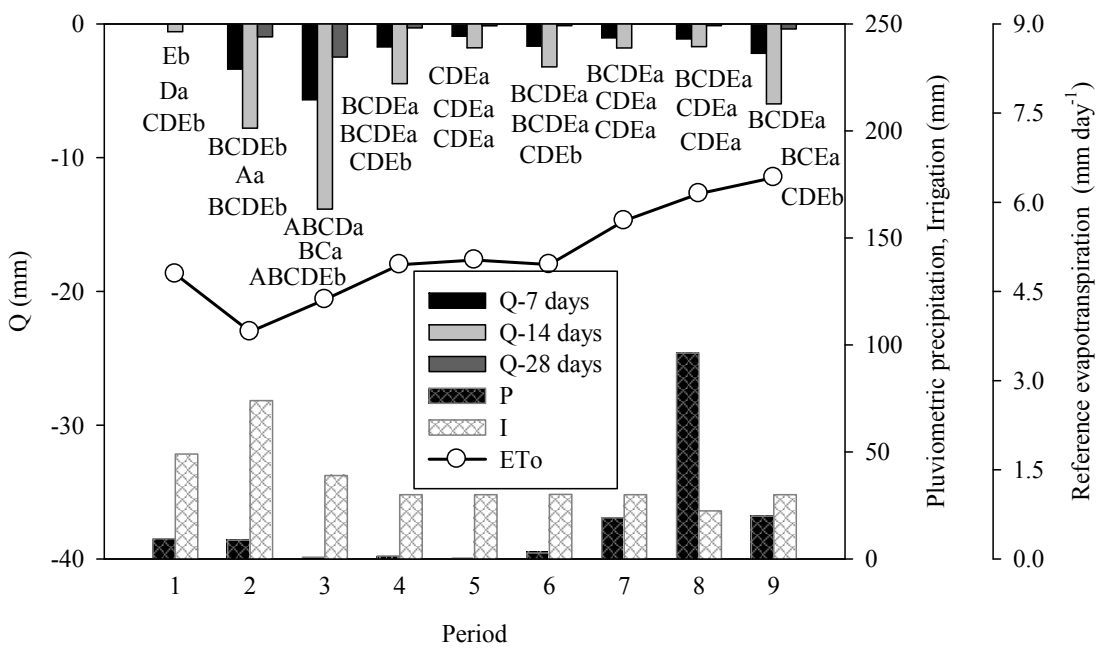

Figure 1. Vertical flow of soil water (Q) as a function of the cycle period (PE, periods 1 to 9 , where each represents 28 days) (a); irrigation condition (IC, $7.5 \mathrm{~mm}$ every 7, 14, and 28 days) (b); and their interaction with each other (PE x IC) (c); pluviometric precipitation (P), irrigation (I), and daily ETo (daily reference evapotranspiration) in a cultivation area with three forage cactus clones (IPA Sertânia [IPA]: Nopalea sp., Miúda [MIU]: Nopalea sp., Orelha de Elefante Mexicana [OEM]: Opuntia sp.) in the municipality of Serra Talhada-PE. *Means followed by the same capital letters throughout the cycle periods do not differ statistically from one another over time. Means followed by the same lowercase letters in the same cycle period do not differ statistically from one another. In graph "c," the set of letters refers, from top to bottom, to the 7-, 14-, and 28-day conditions, respectively. 
(a)
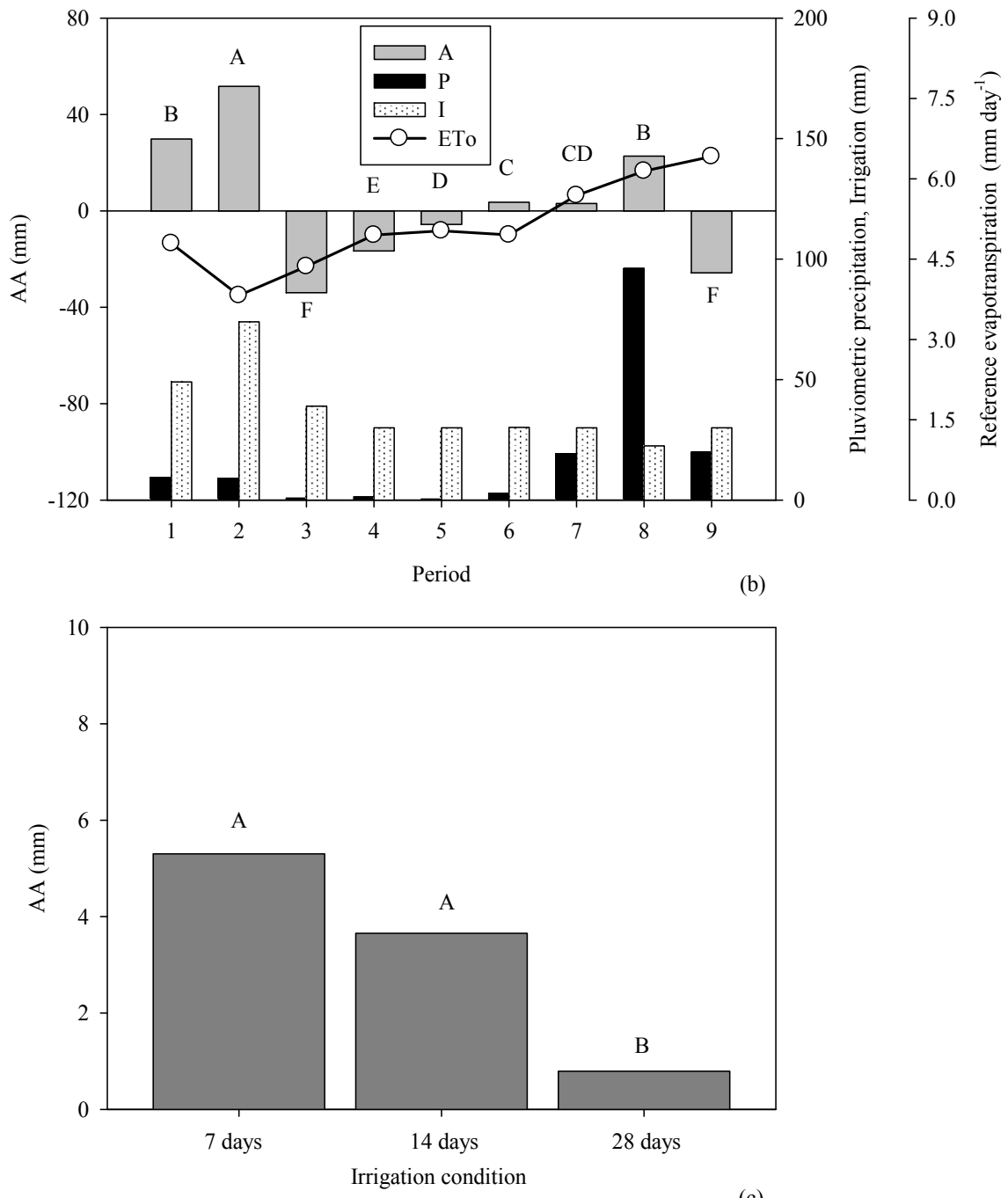

(c)

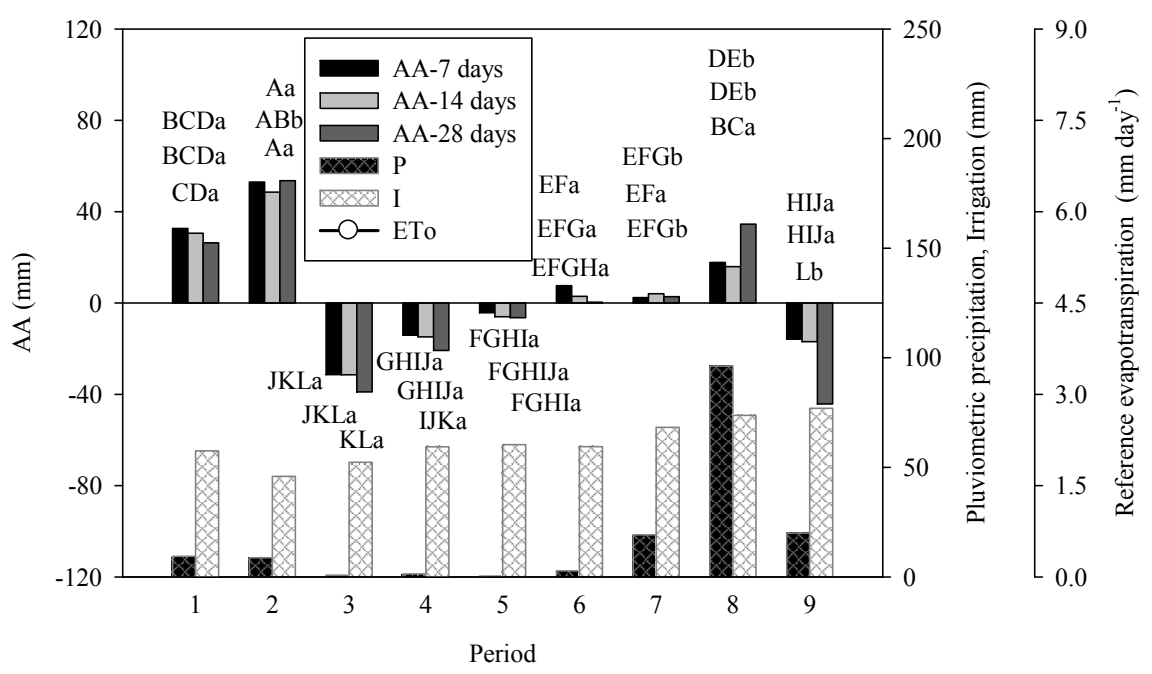

Figure 2. Variation of soil water storage (WS) as a function of the cycle period (PE, periods 1 to 9 , where each represents 28 days) (a); irrigation condition (IC, $7.5 \mathrm{~mm}$ every 7 and 28 days) (b); and their interaction with each other (PE x IC) (c); pluviometric precipitation (P), irrigation (I), and daily reference evapotranspiration (ETo) in a cultivation area with three forage cactus clones (IPA Sertânia [IPA]: Nopalea sp., Múdina [MIU]: Nopalea sp., Orelha de Elefante Mexicana [OEM]: Opuntia sp.) in the municipality of Serra Talhada-PE. *Means followed by the same capital letters throughout the cycle periods do not differ statistically from one another over time. Means followed by the same lowercase letters in the same cycle period do not differ statistically from one another. In graph "c," the set of letters refers, from top to bottom, to the 7-, 14-, and 28-day conditions, respectively. 
(a)
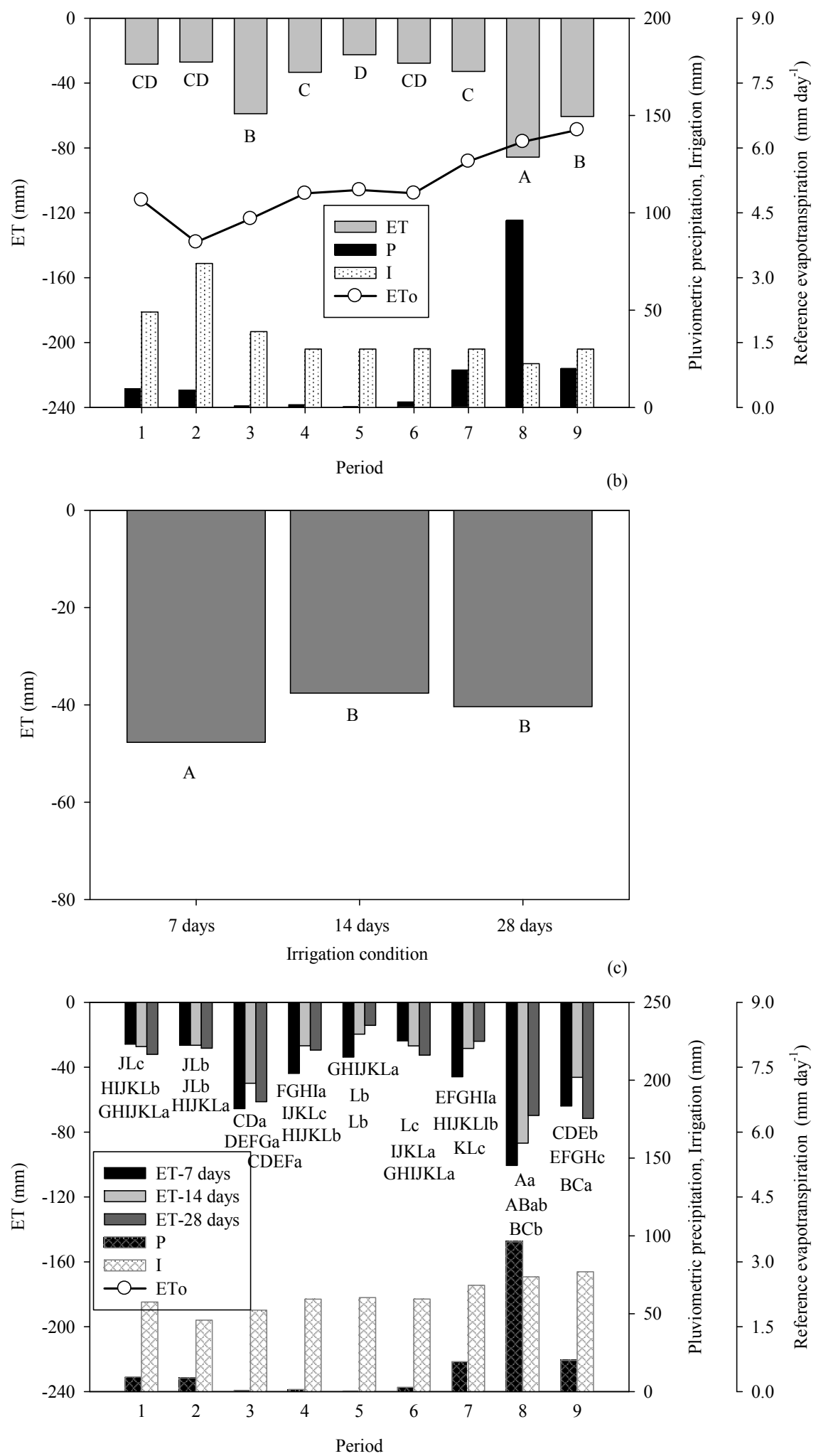

Figure 3. Actual crop evapotranspiration (ET) as a function of the cycle period (PE, periods 1 to 9 , where each represents 28 days) (a); irrigation condition (IC, $7.5 \mathrm{~mm}$ every 7, 14, and 28 days) (b); and their interaction with each other (PE x IC) (c); pluviometric precipitation (P), irrigation (I), and daily reference evapotranspiration (ETo) in a cultivated area with three forage cactus clones (IPA Sertânia [IPA]: Nopalea sp., Miúda [MIU]: Nopalea sp., Orelha de Elefante Mexicana [OEM]: Opuntia sp.) in the municipality of Serra Talhada-PE. *Means followed by the same capital letters throughout the cycle periods do not differ statistically from one another over time. Means followed by the same lowercase letters in the same cycle period do not differ statistically from one another. In graph "c," the set of letters refers, from top to bottom, to the 7-, 14-, and 28-day conditions, respectively. 
Table 1 shows the cumulative values of SWB components. Although there was an effect of the factors of irrigation condition and clone and their interactions on the periods of the crop cycle, there was no isolated effect of the clone factor and the interaction with the irrigation condition in the cumulative values of 252 days $(\mathrm{p}>0.05)$.

Table 1. Cumulative values of pluviometric precipitation and irrigation $(P+I)$, vertical flow of soil water $(Q)$, variation of soil water storage (WS), cumulative actual evapotranspiration (ET), and mean daily actual evapotranspiration (ET [day]) of an area cultivated with three forage cactus clones (IPA Sertânia [IPA]: Nopalea sp., Miúda [MIU]: Nopalea sp., Orelha de Elefante Mexicana [OEM]: Opuntia sp.), under irrigated conditions (7.5 mm with frequency of 7, 14, and 28 days), in the municipality of Serra Talhada-PE.

\begin{tabular}{|c|c|c|c|c|c|}
\hline & Components & & Clones & & \\
\hline Irrigation condition & & IPA & MIU & OEM & Mean \\
\hline \multirow{5}{*}{7 days } & $\mathrm{P}+\mathrm{I}$ & 494 & 494 & 494 & 494 \\
\hline & $\mathrm{Q}$ & -30 & -12 & -11 & $-18 \mathrm{AB}$ \\
\hline & WS & 54 & 44 & 46 & $48 \mathrm{~A}$ \\
\hline & ET (cum.) & -411 & -439 & -439 & $-429 \mathrm{~A}$ \\
\hline & ET (day) & -1.6 & -1.7 & -1.7 & $-1.7 \mathrm{~A}$ \\
\hline \multirow{5}{*}{14 days } & $\mathrm{P}+\mathrm{I}$ & 411 & 411 & 411 & 411 \\
\hline & $\mathrm{Q}$ & -66 & -23 & -34 & $-41 \mathrm{~A}$ \\
\hline & WS & 26 & 31 & 41 & $33 \mathrm{~A}$ \\
\hline & ET (cum.) & -319 & -358 & -336 & -338 B \\
\hline & ET (day) & -1.3 & -1.4 & -1.3 & $-1.3 \mathrm{~B}$ \\
\hline \multirow{5}{*}{28 days } & $\mathrm{P}+\mathrm{I}$ & 374 & 374 & 374 & 374 \\
\hline & $\mathrm{Q}$ & -2 & -2 & -10 & $-5 \mathrm{~B}$ \\
\hline & WS & 22 & -4 & 3 & $7 \mathrm{~B}$ \\
\hline & ET (cum.) & -351 & -376 & -362 & $-363 \mathrm{~B}$ \\
\hline & ET (day) & -1.4 & -1.5 & -1.4 & $-1.4 \mathrm{~B}$ \\
\hline \multirow{5}{*}{ Mean } & $\mathrm{P}+\mathrm{I}$ & - & - & - & - \\
\hline & $\mathrm{Q}$ & -33 & -12 & -18 & -21 \\
\hline & WS & 34 & 24 & 30 & 29 \\
\hline & ET (cum.) & -360 & -391 & -379 & -377 \\
\hline & ET (day) & -1.4 & -1.6 & -1.5 & -1.5 \\
\hline
\end{tabular}

*Means followed by the same vertical capital letters do not statistically differ between themselves under the different irrigation conditions $(7,14$, and 28 days) by Tukey's mean test $(\mathrm{p}>0.05)$.

There was an effect of the factor irrigation condition, where $Q(p<0.01, F=6.7)$, represented by $\mathrm{DD}$, and $\mathrm{WS}(\mathrm{p}<0.01, \mathrm{~F}=8.5)$ were higher in the conditions of greater water availability $(7.5 \mathrm{~mm}$ every 7 and 14 days), although the DD of the first one did not differentiate from the 28-day irrigation frequency (Table 1). On the other hand, in the 7-day irrigation condition, forage cactus presented higher cumulative ET due to higher soil water supply $(494 \mathrm{~mm})(\mathrm{p}<0.01, \mathrm{~F}=18.0)$. The surface runoff was low, being less than $1 \%$ of rainfall. Many studies of soil water dynamics neglect this component (CASTELLANOS et al., 2013; SOUZA et al., 2013).

In the 252 study days (June 2012 to February 2013), the forage cactus had a cumulative ET of 377 $\mathrm{mm}$, equivalent to $1.5 \mathrm{~mm} \mathrm{day}^{-1}$ (Table 1). These values were close to those obtained by Han and Felker (1997) in a study conducted over two years in Kingsville, Texas, United States of America. The authors obtained Opuntia ellisiana ET values of 1.5 and $1.4 \mathrm{~mm} \mathrm{day}^{-1}$ when the annual precipitation was 883 and $662 \mathrm{~mm}$, respectively.

Silva et al. (2015), in an experiment carried out in Serra Talhada, PE, during a two-year period, observed cumulative ET of $1173.3 \mathrm{~mm}$, with a daily average of $2.4 \mathrm{~mm} \mathrm{day}^{-1}$. On the other hand, Consoli, Inglese and Inglese (2013), in the Mediterranean region of Sicily, Italy, adopting the micrometeorological method of turbulent vortices, found for Opuntia ficus-indica L. (Mill.) an average of $2.5 \mathrm{~mm} \mathrm{day}{ }^{-1}$, with the crop receiving a $1360.3 \mathrm{~mm}$ depth of irrigation plus precipitation. Silva et al. (2014) report that this low ET gives the forage cactus higher WS capacity in the cladodes and greater stability of forage production during drought periods.

The ratio between the ET of the forage cactus and the ETo (ET/ETo) presented a wide variation due to the seasonality of the water regime (Figure 4). The highest ET/ETo values were observed in period $8(0.50 \pm 0.02)$, whereas the lowest values were found in period $5(0.16 \pm 0.01)$, due to the absence of precipitation events and low water replacement by irrigation. On average, the ET/ETo ratio was $0.29 \pm$ 0.12 . 


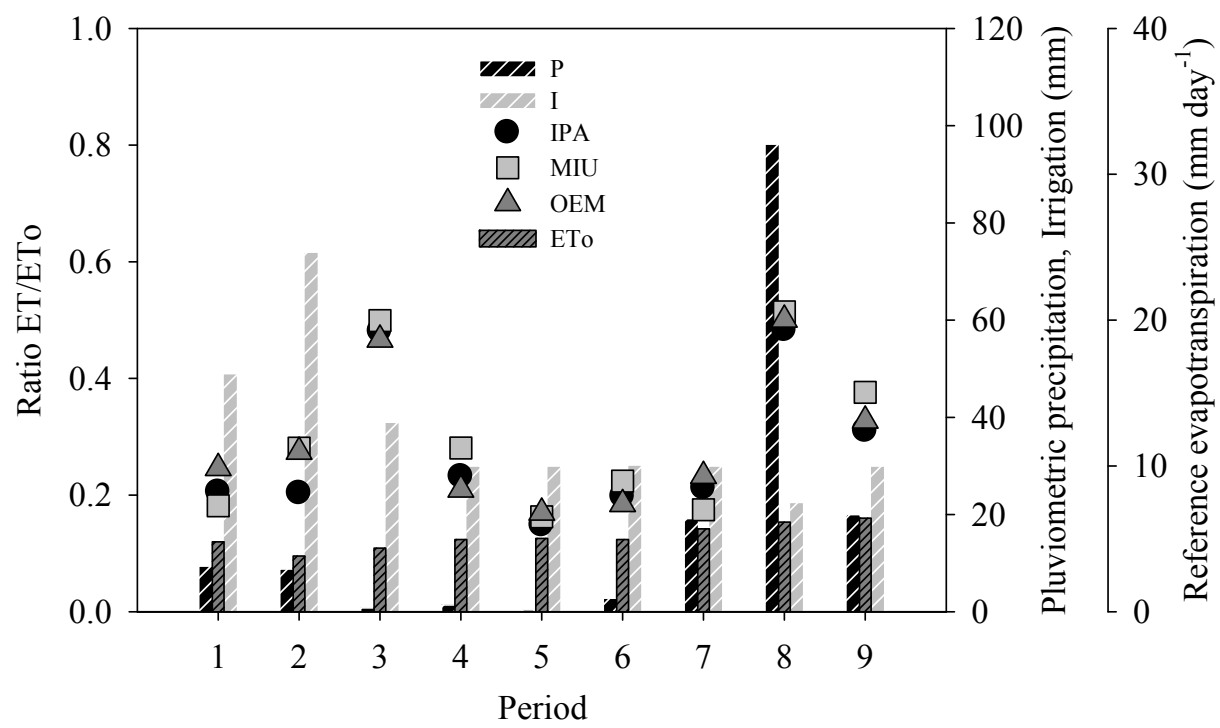

Figure 4. Ratio between the actual evapotranspiration (ET) and the reference evapotranspiration (ETo) for three forage cactus clones (IPA Sertânia [IPA]: Nopalea sp., Miúda [MIU]: Nopalea sp., Orelha de Elefante Mexicana [OEM]: Opuntia sp.) under irrigated conditions, pluviometric precipitation (P), irrigation (I), and ETo of the municipality of Serra Talhada-PE.

Silva et al. (2015) verified a similar result to the present work, in which the highest values of this ratio were identified in the periods of major rainfall events, especially for the MIU and OEM clones, with values higher than 1 . On the other hand, for the period of lowest rainfall index and increased atmospheric demand, these authors found an average of less than 0.20. In the Mediterranean climatic conditions of Sicily, Italy, Consoli, Inglese and Inglese (2013) obtained values ranging from 0.25 to 0.50 for a 6 -year-old forage cactus under irrigation, with an average of 0.40 .

\section{CONCLUSIONS}

The components of vertical flow of soil water, variation of soil WS, and ET did not present differences among the clones, even those belonging to different genera (Nopalea and Opuntia) of forage cactus. Despite the use of irrigation, ET and precipitation were the most important components in the water balance of the soil cultivated with forage cactus clones. The seasonality of the rainfall during the cactus cycle was determinant in the alteration of SWB components, but their magnitudes varied according to the water availability condition $(7.5 \mathrm{~mm}$ every 7, 14, and 28 days). The ET of the forage cactus was more influenced by the low soil water availability than by the atmospheric demand.

\section{ACKNOWLEDGMENTS}

We thank FACEPE for the financial support (process no. APQ-0215-5.01/10) and $\mathrm{CNPq}$ for granting the scholarship.

\section{REFERENCES}

ALLEN, R. G. et al. Crop evapotranspiration: Guidelines for computing crop water requirements. Rome: FAO, 1998. 301 p.

ARAÚJO PRIMO, J. T. et al. Calibração de sondas capacitivas, funções físico-hídricas e variação do armazenamento de água em um argissolo cultivado com palma forrageira. Revista Ceres, Viçosa, v. 62, n. 1, p. 20-29, 2015.

CASTELLANOS, M. T. et al. Impact of nitrogen uptake on field water balance in fertirrigated melon. Agricultural Water Management, Amsterdam, v. 120, n. 1, p. 56-63, 2013.

CHILUNDO, M. et al. Effects of reduced irrigation dose and slow release fertilizer on nitrogen use efficiency and crop yield in a semi-arid loamy sand. Agricultural Water Management, Amsterdam, v. 168, n. 1, p. 68-77, 2016.

CONSOLI, S.; INGLESE, G.; INGLESE, P. Determination of evapotranspiration and annual biomass productivity of a cactus pear (Opuntia ficus-indica L. (Mill.) orchard in a semi-arid environment. Journal of Irrigation and Drainage Engineering, Amsterdam, v. 139, n. 8, p. 680-690, 2013.

DUBROVSKY, J. G.; NORTH G. B.; NOBEL, P. S. Root growth, developmental changes in the apex, 
and hydraulic conductivity for Opuntia ficus-indica during drought. New Phytology, Amsterdam, v. 138, n. 1, p. 75-82, 1998.

GHIBERTO, P. J et al. Components of the water balance in soil with sugarcane crops. Agricultural Water Management, Amsterdam, v. 102, n. 1, p. 1-7, 2011.

HAN, H.; FELKER, P. Field validation of water-use efficiency of the CAM plant Opuntia ellisiana in south Texas. Journal of Arid Environments, Amsterdam, v. 36, n. 1, p. 133-148, 1997.

HERNÁNDEZ, A. F. et al. Yield and physiological traits of prickly pear cactus 'nopal' (Opuntia spp.) cultivars under drip irrigation. Agricultural Water Management, Amsterdam, v. 70, n. 1, p. 97-107, 2004.

HOWELL, T. A. et al. Evapotranspiration, water productivity and crop coefficients for irrigated sunflower in the U.S. Southern High Plains. Agricultural Water Management, Amsterdam, v. 162 , n. 1, p. 33-46, 2015.

KIREMIT, M. S.; ARSLAN, H. Effects of irrigation water salinity on drainage water salinity, evapotranspiration and other leek (Allium porrum L.) plant parameters. Scientia Horticulturae, Amsterdam, v. 201, n. 1, p. 211-217, 2016.

KRESOVIĆ, B. et al. Grain yield and water use efficiency of maize as influenced by different irrigation regimes through sprinkler irrigation under temperate climate. Agricultural Water Management, Amsterdam, v. 169, n. 1, p. 34-43, 2016.

LIBARDI, P. L. Dinâmica da água no solo. São Paulo, SP: EDUSP - Editora da Universidade de São Paulo, 2005. 335 p.

OLIVEIRA JUNIOR, $\mathrm{S}$. et al. Crescimento vegetativo da palma forrageira (Opuntia ficus-indica) em função do espaçamento no semiárido paraibano. Tecnologia \& Ciência Agropecuária, João Pessoa, v. 3, n. 1, p. 7-12, 2009.

OLIVEIRA, A. S. C. et al. A palma forrageira: alternativa para o semi-árido. Revista Verde, Mossoró, v. 6, n. 3, p. 49-58, 2011.

QUEIROZ, M. G. et al. Características morfofisiológicas e produtividade da palma forrageira sob diferentes lâminas de irrigação. Revista Brasileira de Engenharia Agrícola e Ambiental, Campina Grande, v. 19, n. 10, p. 931-938, 2015.
SCALISI, A. et al. Cladode growth dynamics in Opuntia ficus-indica under drought. Environmental and Experimental Botany, Amsterdam, v. 122, n. 1, p. 158-167, 2016.

SILVA, T. G. F. et al. Indicadores de eficiência do uso da água e de nutrientes de clones de palma forrageira em condições de sequeiro no Semiárido brasileiro. Bragantia, Campinas, v. 73 , n. 2, p. 184-191, 2014.

SILVA, T. G. F. et al. Soil water dynamics and evapotranspiration of forage cactus clones under rainfed conditions. Pesquisa Agropecuária Brasileira, Brasília, v. 50, n. 7, p. 515-525, 2015.

SNYMAN, H. A. Root distribution with changes in distance and depth of two-year-old cactus pears Opuntia ficus-indica and O. robusta plants. South African Journal of Botany, Amsterdam, v. 72, n. 3, p. 434-441, 2006.

SOUZA, C. et al. Balanço hídrico da cultura da mamona sob condições de sequeiro. Revista Brasileira de Engenharia Agrícola e Ambiental, Campina Grande, v. 17, n. 1, p. 3-10, 2013.

TARI, A. F. The effects of different deficit irrigation strategies on yield, quality, and water-use efficiencies of wheat under semi-arid conditions. Agricultural Water Management, Amsterdam, v. 167, n. 1, p. 1-10, 2016.

WARD, P. R. et al. Soil water balance with cover crops and conservation agriculture in a Mediterranean climate. Field Crops Research, Amsterdam, v. 132, n. 1, p. 33-39, 2012. 